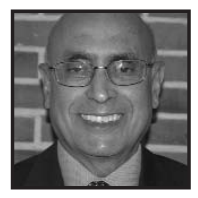

\title{
Life-Long Readers of Poetry? Why Not?
}

\author{
Patrick Dias, McGill University
}

\begin{abstract}
I have come to believe that most students who have read and studied poetry in school and college do not go on to read and enjoy poetry in their adult lives because they do not expect to understand a poem of any complexity on their own. Unfortunately, years of conditioning into such dependence have also victimized teachers into functioning as guardians of the poem's meaning. In an attempt to find out what students could realize from a poem without teacher direction, I discovered in studies at various levels of schooling that students working in small groups without any expectation that the teacher held and would provide "the one right meaning," generated rich and powerful readings of challenging poems far beyond any understanding that the teacher could have mediated with questions.
\end{abstract}

\section{Introduction}

n January 2009 the National Endowment for the Arts in the United States reported in a summary research report that the number of American adults who had read a work of fiction in 2008 , had risen to $50.2 \%$, higher by $3.2 \%$ than the results reported in 2002 (Reading on the Rise: A New Chapter in American Literacy). This increase represents a reversal of a trend in declining readership; however, in sharp contrast the report also announced that only $8.9 \%$ of adults admitted having read any poetry in the previous year, a decline from $12.1 \%$ in 2002 , and $17.1 \%$ in 1992, only 16 years earlier. I am not surprised by the results, for when I have spoken to adults about reading and asked them to recall when it was that they last read a poem with any degree of attention, invariably, the vast majority of them when pressed admit that they have not deliberately read a poem since high school or university. 
It is remarkable that while most adults regularly read newspapers, magazines, short stories and longer fiction, reading poems with some degree of attention invariably remains associated with the classroom, which raises a question: while there are powerful arguments for the inclusion of poetry in the school curriculum, arguments rooted in the historical and universal belief in poetry's aesthetic and moral values, should we not be alarmed that our teaching of poetry and our belief in the significance of poetry to the lives of people produces only a few potential consumers of this vital good?

\section{Overcoming resistance to poetry: Poems as everyday items?}

How do we make poetry matter? The question has engaged librarians, teachers, and poets in several countries to initiate with the collaboration of town councils and education authorities the placement of poems on billboards and posters in public places such as shopping malls and town centres. An appealing approach called variously Poems on Buses, Poetry in Motion, Poetry in Transit, or Poems on the Underground, presents short poems riders can read between stops. Check out the London Underground Web site to sample the poems the tube riders are exposed to (http://www.tfl.gov.uk/corporate/projectsandschemes/2437.aspx). Using poetry in these ways not only keeps poetry in the public eye, but it also promotes the notion of poems as familiar objects like public advertisements, all easily accessible and with a take-it-or-leave-it approach to them. The process of making poems familiar, comfortable objects (who's afraid of the big bad poem?) has obvious extensions to the classroom with the posting daily of a short poem, so that students begin to look forward to seeing and hearing a fresh poem each day, no questions asked, no explanations sought.

\section{Cultivating ownership of and responsibility for one's reading}

The familiarization aspect of this process is only a first step in the larger agenda of developing reflective, committed readers of poetry. What I am set on cultivating here is the role of students as primarily responsible for the meanings they make and not dependent on the teacher for the correct reading and the final word on the poem. In the words of Louise Rosenblatt's well-known admonition,"no one can read a poem for you" (Rosenblatt, 1978, p. 86). Such dependence persists from kindergarten to university and is hard to break. The notion of the teacher as the person to whom students are accountable for the right reading is at the core of students' fear of poetry and their reluctance to read poems of their own accord. I have so often heard students and even adults say that a poem rarely turns out to "mean" what they 
think it means, and what it usually turns out to mean is the reading that the teacher provides. Such realizations, borne out repeatedly, build up a distrust of their own responses to a poem, and as a defensive measure a disinclination to entertain any reading or interpretation until they have some sign from the teacher's questioning of the direction in which they must proceed. A game of "Am I getting warm? or "Am I still cold?" is in constant play in the interchange between teacher and students. What is even more damaging to the students' confidence as readers of poetry is the seemingly perfect obviousness of the teacher's interpretation.

There is very little satisfaction to be derived from reading poetry if in most encounters the poem remains seemingly impenetrable. However, I have often been challenged with the question, "How then do children and adults manage to read stories and long fiction independently?" But then, stories have been and are in our lives from very early childhood. From the first "once upon a time," children are well on their way to recognizing and being alert to story genres. Unlike with poems, they are seldom asked what a story means. The question simply doesn't arise. As Barbara Hardy put it, "narrative is a fundamental act of mind" (Hardy, 1977). In whatever way stories may operate in our own lives, the study and reading of poetry remains very much a school subject.

As someone involved in teacher education, I used to be reminded of this apathy towards poetry, or more correctly, the fear of poetry, every time my students faced the prospect of student-teaching. When they met their classes and announced they were going to teach poetry, there was inevitably a collective sigh amounting to "Oh, not poetry!" Even though most of the student-teachers were fresh from their majors in literature, they had seemingly not shed their own uncertainty about how and what a poem means. When I read a poem aloud and invited them to speak about their responses, I was met initially with a general reluctance to make more than a few obvious observations. When I queried them about their uncertainty, there was an eruption of how often they had held back their own observations because they had often turned out to be far removed from the authoritative reading the lecturer offered. Inevitably they learned to read the lecturer's clues toward the preferred reading.

\section{The role of the teacher: Steps toward developing self-reliant readers of poetry}

Convinced that school practices in the teaching of literature cultivated a dependence on the teacher as the holder of "the one right reading," I decided to 
explore what would occur if teachers abdicated their roles as intermediaries between poem and students, trusting them to make sense of the poem on their own, without the least expectation that the teacher would intervene to set them right when they strayed. For those assumptions to operate, the teacher would function as one who truly did not have answers, someone genuinely curious about the students' responses to the poem and expecting to be informed by those responses. In the context of schooling this is an alien role for teachers to adopt, but it is not difficult once it is taken on without pretence or dissimulation. Thus began the first of my many forays into the classroom in a search for answers.

The solutions I offer derive from almost two decades of such forays at different levels of schooling, deliberate testing and retesting of procedures in classrooms, collection and analysis of tape-recorded group sessions and individual interviews, discussions of findings with colleagues and presentations at conferences and workshops with teachers and a great deal of reflection, discussion, and writing. However, the key principles that undergird the procedures I now advocate took their shape during the first study I conducted in a Grade 11 classroom.

It was during that Grade 11 study I realized I had a natural advantage as a researcher from McGill; for students understood immediately that I was truly dependent on them for the information they could provide as to how they read and understood some challenging poems. That I tape-recorded their discussions confirmed my intentions. All I did was establish a procedure where after three readings aloud of the poem (by me and two volunteers), the students proceeded in previously assigned groups of five or six, to read the poem, share their initial responses, and then examine the poem in convenient chunks. Towards the end of the discussion period (they were allowed twenty-five minutes), they were to help their reporter to put together what they would report to the other groups. ${ }^{1}$ The reporter took no written notes and had to report extemporaneously with the injunction to build on and take account of the previous reporters' comments. Time permitting, members of the group were invited to provide additional observations.

Several aspects of this process worked fortuitously for me (I have provided just enough detail for readers to grasp the general pattern of the process; there are several details, some of them cautionary, that need to be considered. Since I have written about this procedure several times, there are a number of sources readers can consult ${ }^{2}$ ). I provided when requested the dictionary meanings of words that were unfamiliar to the class, leaving them to work out the sense within the context. Several days into the ten-day period I had planned for the project, the students stopped 
asking me about unfamiliar vocabulary, finding that the literal meanings often misled them, whereas they were more likely to get a better sense of the meaning from the larger context of the poem. I had asked them to be attentive to the feelings the poem evoked as they heard it, reminding them that poems often work at the level of sensation. Often such awareness provided an affective layer of understanding that curbed flights into abstraction, but more importantly, provided a key entry into the poem.

Limiting the discussion to 20-25 minutes was a practical necessity in a 45 minute period, but it provided the thrust needed to focus on composing a report, which was to be a summation of where they had arrived, their own differences, and the questions they needed to have answered by the other groups. Slowly the collaboration within the groups had extended to interdependence among the groups; together they were composing their response to the poem.

Several times as I circulated among the groups and found that a group had stalled, I encouraged them to read the poem aloud (poems need to be heard), be attentive to their feelings, and surely enough, they discovered in that rereading the points they had to return to or explore. In a few days I realized that they had adopted multiple readings as a strategy for breaking through an impasse. Often I counted between four and six readings during that short period of discussion. Such a demand coming from me would have been regarded as an unwarranted imposition.

Not taking or working from notes turned out to be a fortuitous decision; since the reporter had to speak extemporaneously, he or she often rehearsed the report in the last few minutes before the session was called. The rehearsal was highly collaborative, the group reviewing high points and promising to prompt the reporter if he or she had difficulty remembering. Moreover, not working from notes ensured the reporter was alert to what was being said by other reporters, and this often led to realizations about the poem that had not emerged in the actual discussion. Thus the members of the group were pleasantly surprised at these newer realizations. Sometimes, when a reporter had taken notes surreptitiously, the ruse became obvious. Relying on the notes, the reporter was paying little heed to what had gone before, and thus repeated much of what had already been reported.

In the first few days of this procedure, I was always asked after the reporting stage whether I would finally tell them what "the real meaning" of the poem was. This was a critical moment; I needed to tread lightly and said that I had heard so much during the discussions and from their groups' reports that I needed to reconsider my own response; so we needed to do one final reading. Several days later, knowing this 
explanation had been accepted, I asked them after the reporting had concluded if they would like to know what I thought, and I received a resounding "no." They had moved from assuming that I had the "right" interpretation to the absolutely exciting (for me) realization that my interpretation (however appealing) was more likely to cut short or impede their own exploring.

Through all this without explicit instruction, they had become sharp, attentive, and confident readers of poetry. Moreover, their teacher reported that they were far more fluent and reflective as writers. What else could we have expected? Intense discussions of poetic text about issues of some significance in words that evoke feeling and concrete images cannot but flow into their writing. A few years later, a teacher replicating the procedure with her class of 14-year-olds told me that the students' journal entries on the poems they discussed each day had got longer and more elaborate and organized than she had expected, and that the students had become acrimonious about the additional writing demands they had unwarily taken on. The truth is that in revisiting a poem each evening they were unable to constrain their responses and the writing that followed. There was a felt need to explore, clarify, and elaborate to themselves their own understandings. With the exception of the group I have just referred to, all the classes I worked with were mixed-ability groups. I was anxious that teachers recognize that poetry was accessible to readers of all ages and abilities, and by poetry I do not mean light verse intended primarily to amuse.

\section{The teacher not a mediator between reader and text; the teacher as "needing to know"}

I need to stress here that in all my relationships with the students, I am always in the position of needing to know from them, but I am not the focus of their attention. They are not accountable to me but to one another within the group and to the other groups. The task the group takes on is always held in common, so that the reporting-back phase trades on their curiosity about the responses of others and their similarities and differences. Because they are more powerful in groups and because they are collectively creating a full and rich account, the poem or the story or novel is explored in some depth and in its relationship to their lives in ways I could never expect to replicate through teacher questioning and instruction. In the close comfort of a small group it is easier to say, something personal and private like, "This is just like the time when my parents embarrassed my brother." Moreover, it is very clear that what they know and have grasped is the common possession of every student to deal with in whatever way she or he finds relevant. 
What is also important to recall here is that at no time has it ever been necessary for me to pitch in and tell them what it is I as an adult reader recognize that they as younger readers may not have realized. Such information is not relevant to their development as readers. Those who have qualms about not meeting "their responsibilities" as teachers, should take comfort in the fact that time and time again these students have gone far and beyond anything I could tell them. I feel extremely privileged to hear their twelve- or sixteen-year-old readings, a perspective I shall never fully recover without a time machine. We need to keep in mind constantly that we have lived longer, read much more, experienced new life, love, and longing, and death, and all that living will afford us a perspective on the poem at some remove from what they will have realized. No wonder then that they remain puzzled by how we arrive at where we have arrived when we offer them our reading and they must accept it as, of course, the authorized reading.

I can assure teachers that taking the stance of "needing to know" does not preclude providing any information the students seek or naming a particular device or strategy they have identified and do not have a label for. At such a time I have no quarrel with telling them that a particular comparison is what we call a metaphor or a simile, and now that they have felt the force of the particular image, they will be recalling the label in terms of their own experience rather than as an abstract definition, which is often the case. But again, the important work is to be particularly concerned to support their growing (collective) autonomy as readers.

I must admit that several years ago in Baltimore at a conference of English teachers, I was taken to task by a teacher for denying the teacher her voice. She insisted that she had a voice and the right to express her opinions and at the same time the students had a right to know what she thought. I pointed out that a teacher spoke with such authority that her voice would doubtless silence the budding ideas and formulations that are often so fleeting and fragile that they are very difficult to hold on to. I would have gone on to say that the reward for withdrawing from the centre is a group of students who feel so urgently the wanting to say something, that they resent the bell that announces the end of the period. "Oh damn," said one, as the bell rang for the end of the day, and their puzzled friends stood outside the classroom wondering why the door had not flown open as it usually did at the end of the school day. The students' engagement was stunning to observe, matters had to be resolved before they broke up, or the moment would be lost. Other groups remained similarly engaged, and my small group of McGill students, distributed among the groups, were going to miss their next class at the university because they were too embarrassed to leave before their hosts. 
As I write, I have in front of me a note from a teacher in Fairbanks, AK: "My class has just ended; and they are leaving in clusters still talking about the poem. I have never seen anything like this before. Thank you."

\section{Small-group work versus teacher-led discussion}

After the first study I conducted with Grade 11 students, I looked for ways I might extend the study by working with younger students. Susan (all names are pseudonyms), a teacher in a Laval comprehensive school, offered me three of her Grade nine English classes for this study. I decided to work with one mixed-ability class and she with another; I requested that she teach the third group, a higher ability group, the same set of poems in the way she would normally have taught them. In other words, I was setting up the two low-to-middle range students involved in group work for comparison with the higher ability class studying the same poems with teacher direction. We agreed on the poems we would use over the ten sessions we had allowed for and set up the normal pre- and post-test procedures in order to track how students may have benefited from the procedure. I must make clear that the poems I use are always challenging, likely to engage the students, and at first glance not easy to grasp. My criterion is that the poem should justify group effort and collaboration, so that considerable discussion is generated and students return often to the text and are not unrewarded. ${ }^{3}$

Three or four days after the work began, Susan begged off teaching the higher ability group and asked that they be involved in the same small-group process as the other two classes. Just over two days, Susan had begun to notice that her smallgroup class was realizing far more from the poems on their own than were the students she was teaching directly. Despite all her attempts to engage those higher ability students, she was far too aware of the observations and insights the small-group class was reporting without any direct intervention from her. Those two classes (my own class included) were intensely occupied, whereas her "top class," as she labelled them, were bored and almost rebellious; for they had heard from their friends in the other two classes, that they were "having fun." Even in the interests of gathering important data, Susan was not prepared to impose her teaching on those students; the experiment had already produced results, there was no reason to extend it. I had no intention of trying to change her mind, but I asked anyway: "Wouldn't you have been teaching in the way you now reject if this project had not come along?" "Yes," she agreed, "but it would have been because I didn't know any better." (Susan, personal communication, May 1983) 
In any case, the small-group work continued, and I saw my own mixedability group through to the end of the program we had planned. It was soon clear to the students that no poem was ever "done" in the time that was available. They left the class with more questions than they had begun with, but they knew they would revisit the poem that evening and be able to compose an account for their journals, sensing that in the time between new insights may have arisen, and the poem was no longer the poem they had just finished discussing. Each day with each new poem was an occasion for all of us to wonder where we were going and where we would end up. I have several anecdotes but I shall limit myself to just one.

I had asked the teacher to group the students so that they would get along with one another and no group would be overly dominant or reticent. When I entered the class for the first time, I noticed a group made up exclusively of boys, unlike the other groups which were a mix of boys and girls. The teacher explained that these were the students who were likely to be disruptive; and so they were somewhat segregated from the other groups under the watchful eye of the teacher. Contrary to our expectations the boys got caught up in the process, in the autonomy they were accorded, in the fact that they were always rushed for time, and ultimately in the interdependence among the groups that required that they attend to the other groups and in turn expect full attention from the others. Thus their first halting reports grew longer and more confident. In fact they valued the time they were able to speak out, and when their most reticent member spoke they prompted with supporting comments, all instantly recognized by the speaker, because he had taken ownership of all that had been said. This prompting was an exciting feature in all the reporting back, because I had planned that each member of the group would take a turn reporting for the group. Inevitably because the least confident member's turn came up on the fifth or sixth day, depending on the size of the group, the unsure speaker had had the time and opportunity to learn from what the others had modelled in the previous sessions. Thus there was a remarkable awareness of their joint stake in the outcome; the reporter was speaking for all of them, and it mattered that their contribution was a component of the group understanding that was being coconstructed.

My anecdote comes from this particular group of students. About the eighth or ninth day of the ten-day study, the class had been discussing Frost's "Stopping by Woods on a Snowy Evening" (1922, p. 60). In the final stage of the procedure, the reports from groups, several accounts had been advanced with general agreement about the poet's being drawn away from contemplating this quiet scene by recalling he had promises to keep. The poem was read aloud once more, and I 
asked if anyone in the class could recall an experience similar to the one Frost wrote about. Luigi in the segregated group got my attention, stood up and said:

Yes, one morning when I was coming to school, I noticed a bird flying to its nest. The nest was on a pole on a small ledge where the branch of the light starts. I stopped because I noticed it was feeding its babies. I watched and I could not leave, even though I knew I was going to be late for school. Just like this guy Frost, I kept thinking, I've got to go, I've got to go. But I still waited. (Luigi, personal communication, May 1983)

In that moment we were all linked with Luigi to the heart of that poem.

\section{Poems as expendable}

Often the question comes up, a most teacherly concern, about what happens if the students have not come to certain conclusions about the poem, or (what is worse) if they have the wrong interpretation? Teachers wonder if they should let the poem go without putting them right. This is indeed the sticking point. My response is always that there are thousands of poems in the world, and poets will not turn over in their graves because a misinterpretation has not been checked; poems are expendable, there are other poems. But that may seem flippant; so I always add that intervening as a teacher to put someone right about a poem is a high price to pay for inhibiting the growing confidence that is building. To move from the sidelines from our "not knowing and needing to know" status, to the position of someone who all along had the answers will betray that all the group work, and reporting in groups was a charade. But to a large extent this question is hypothetical. We need to trust the wisdom of the group; among the thirty or so students, there may be a few who offer alternative readings and often, when students reread the poem that evening in order to write a response for their journals, they recognize where they may have misread a line and some other reading they dismissed may have been spot on. Further to assuage any further concern, I remind teachers that we are not going to be around leaning over their shoulders in their private lives as readers to steer them to the interpretations we prefer.

As I mentioned earlier, I had the advantage of meeting students as an outsider, a researcher, who needed to know from them, and therefore students went along with the procedure I proposed (of course, there were strongly supporting teachers who had prepared the ground for my visits). Often teachers who grade and prepare students for public examinations fall in and out of this confidence-building 
and competence-developing role. From what I have observed of a large number of teachers who work with small groups, students who have discovered their capabilities as readers of literature or as writers for that matter, will not easily revert to their passive, "tell-me-what-I-need-to-do-and-I'Il-do-it roles." I do not wish to sound disparaging of some of the teaching in schools, and under some difficult conditions where teachers need to be directive and assertive; however, I know of some "difficult" and "turned-off" classes that have come alive because of the assumption by students of their full responsibilities as learners.

I need to remind myself constantly that for a significant number of teachers the shift I am proposing is quite radical and is hard to swallow. I had gone into classrooms to find out what happened when students in small groups were asked to discuss a poem on their own. I was not seeking a method for teaching poetry. I expected that once I knew what students could do on their own, I could then recommend what teachers ought to do to enable a fuller reading. What I learned very soon was that teachers needed to do very little. In my first foray into schools with this method, I had no expectations of the positive gains that would occur, and when I presented the videotaped evidence to small groups of teachers, I was excited by their response; however, I recognize that as I am asking for a radical shift in outlook and role, there will always be some degree of resistance and skepticism, no matter the promised gains.

\section{Working with younger students}

But that was several years ago. My most recent attempt at extending the approach involved a class of sixth graders in a split English/French program. Enjoying the freedom of early retirement, I planned a six-week program where I worked five days a week, involving the students in small-group work following the procedures I have described. I had the support of a superb teacher and three of my graduate students who helped with recording their observations, but were otherwise not directly involved with the students. My goal this time was to work with writing and with literature (short fiction, novels, and poetry). The whole project provides material for a book-length report, but for this article I wish to describe two events from near the conclusion of my work in the school.

Now that they were used to working in groups, as a closing exercise I asked the students to bring in two poems each, which they would present to their groups and from among those poems the group would settle on the two poems they would present to the whole class to discuss in their own groups, employing the procedure they 
knew fully well. Consider that each group had to read and review in their groups between ten and twelve poems before they could settle on the two that would be worth presenting and discussing in class. In other words, they were functioning as reviewers and critics, roles students are hardly ever called on to exercise. And their choices would have consequences. Not for a moment did any of them feel it was necessary to call on their teacher or me for advice. So much had the groups come to respect the group process that not one of them clamoured to have their poem become the group choice. Interestingly, some parents telephoned the teacher to say how disappointed their children were to discover that there were not any books of poetry in their homes. In any case I had alerted the school librarian who had set out several anthologies of poems which the students could browse.

Most of the poems chosen were fairly challenging ${ }^{4}$ - the students had taken to heart my suggestion that the poem should be interesting and at the same time challenge the resources of the group. Mike, one of the more engaged students in the class, had chosen a poem by Shel Silverstein (from his collection, Where the Sidewalk Ends, 1974) 5 To Mike's dismay the poem generated little discussion in the several groups. The reporters without exception said there was nothing to report, the poem evoked little discussion, and they wondered why Mike had chosen the poem and his group had offered it as one of their choices. There were no losers here. Mike and his group recognized from the other groups' choices where they had fallen short, and what they ought to have offered. I make this point in order to point out that what is learned goes far beyond what can be explicitly taught in a teacher-at-the-centre classroom.

The class teacher had informed me that the parents had noticed over a short time a change in their children's school-related behaviour: increased reading, writing, and an eagerness not to miss school and consequently the opportunity to make a contribution to the group's efforts as well as satisfy a genuine curiosity about where the class as a whole was moving in the group project. The parents had been advised formally about the project, but wanted to know more. So it was meet-theparents night for me. I was even more surprised when on the eve of this occasion, the students asked to be able to attend with their parents. Of course, they were welcome to do so, said their teacher, but I had known from experience that children of that age were particularly averse to being seen anywhere with their parents, and especially not in school.

Their teacher felt it would be interesting if the parents experienced the small-group activity themselves, and we agreed that their children would participate 
but mixed in with the adults, but certainly not with their own parents. I chose a poem which would challenge and also speak to both groups. The evening was successful beyond my expectations. With one exception, the students were persuaded by the parents to be the reporters, especially when the parents discovered they were not permitted to take notes. It was almost immediately clear that the parents were no match for their children in terms of the confidence they displayed. It was obvious that the students had taken charge: there was a great deal to be said (as usual) and the parents appeared uncertain and reticent about their own responses, often deferring to or even soliciting the students' responses. In reporting back to the larger group, the students were fairly articulate and attentive to what had been already reported.There was one exception. The parent who had volunteered to report for her group spoke at some length and it was clear she was speaking for herself rather than for the group. This was an object lesson for the parents who saw how their children were non-competitive and accommodating of the observations of the groups. What impressed the parents was the assurance with which the reporters spoke extemporaneously. Many of the parents informed me later that it was a complete surprise for them to see their children in these unfamiliar roles. Some of them speaking of changes in home behaviour told me how much of a surprise it was for them to see their children reading the newspapers that hitherto had been opened only to the comics page.

It should be clear now that the outcomes I report are not only about poetry. There are applications and modifications that extend to all literary genres and to writing activities as well. I must mention specially the interdependence that develops within and among the groups. All students realize they have a stake with what happens within the group and what is reported. Such membership is exemplary in several respects, and I shall cite only the instance of the students who offered to visit and read to a group member who had reading difficulties, so he could keep up with the assigned reading of the novel each day and thus participate more fully in the group's discussions.

If poems are to be personally appropriated, if students are to realize their full potential as readers of poetry, then they need to have every opportunity to read and talk about challenging poems with the expectation of realizing a full and satisfying reading. Working in groups remains at the core of the practices I advocate. The philosopher, Michael Polanyi has said that "we can know more than we can tell" (1966, p. 4), his point being that much of what we know remains tacit and inexplicit. I believe group work is the most convenient and effective way of affording students the opportunity to speak often and at length from their own realizations, so that they can discover more often what it is they know and hitherto have not had the means and 
the impetus to articulate. Poetry has the advantage of being so immediately available, appealing to the imagination, scornful of cliché, echoing so poignantly and fleetingly the feelings that gnaw at our insides when we recognize them. "Margaret, are you grieving over Goldengrove unleaving?" (Hopkins, 1880, p. 703) asks the speaker in Gerard Manley Hopkins' poem; and a 17-year-old Francophone girl about to cross over to college, sheds a tear as she reflects on the poem in her journal. She wrote later that until she had participated in the poetry group discussion project she had not realized that she was capable of reading and responding to poetry in English, and now had the confidence to apply to a college whose medium of instruction was English. And in Winnipeg, a 14-year-old girl in a bookstore given the choice of a birthday gift by her mother goes directly to the literature section in search of a particular book of poems.

\section{Notes}

1. There was never any suggestion that they should arrive at the "meaning" of the poem. My instructions were to report on their experience of the poem, or to report on what they thought was happening or going on in the poem, or on where they had arrived in their discussion.

2. An abbreviated account and demonstration will be found in "Literary Reading and Classroom Constraints: Aligning Practice with Theory." In J. Langer, Ed., Literature Instruction: A Focus on Student Response, Urbana, IL: National Council Teachers of English, 1992. Fuller accounts are available in Reading and Responding to Poetry: Patterns in the Process (Revised edition). Portsmouth, MA: Boynton/Cook Heinemann, 1996, and in Developing Response to Poetry (with Mike Hayhoe), Milton Keynes, England: Open University Press, 1988.

3. For the kind of poems I have in mind, I offer a small sample of some of the poems I have used with a variety of age groups: William Stafford, Travelling through the Dark and Fifteen, Robert Frost, Stopping by Woods on a Snowy Evening and Fire and Ice, Seamus Heaney, Blackberry-Picking, Follower, and The Early Purges, Al Purdy, Detail, Margaret Atwood, This is a Photograph of Me, Theodore Roethke, My Papa's Waltz, Langston Hughes, Mother to Son, and Hold Fast to Dreams. The latter is short enough to memorize with a few readings and ideal for students who have difficulty reading. Poems hold excellent promise for such students: the several 
oral readings in the class and within the group before discussion begins offer the opportunity to be fully involved and engaged. Children can also be invited to write their own completions to the line, "Life is ..." Longer poems like Earl Birney's David or D. H. Lawrence's Snake are certainly worth offering as fluency and confidence grow. It is unlikely that either of these poems can be fully explored in the time available; however, the sharing among the groups in the reporting-back phase does allow for the emergence of unexplored facets, and then there is always the reading and reflection that occurs later when the students individually reread the poem and draft their journal response.

4. The students' efforts were somewhat frustrated by the limitations of the school library poetry collection, in that the poems were age appropriate for independent reading and as could be expected, not sufficiently challenging. The poems that the students chose as challenging were either early Victorian or World War I poems. If I were to repeat this exercise, I would ensure that the library was stocked with some of the more attractive poetry collections that are widely available and include some poems that are accessible across a broad age range.

5. This is not to disparage some of Silverstein's work as not worth reading; the point is that there are many poems that are worth reading and one can recall with pleasure, but do not call for group effort.

\section{Acknowledgments}

I am deeply indebted to so many teachers and English consultants who afforded me access to classrooms, which allowed me to explore the real abilities of students as readers of poetry and also develop approaches to enable their growth as readers. So many people helped me that it is with some trepidation I mention only a few of these benefactors: Alan Patenaude and Suzanne Duquette in Laval, Linda Fernandes, Gerry Foley, Anthony Paré, and Anne Peacock in Montreal, Heather McBride in Baie D'Urfé, Quebec, Coralie Bryant and Rudi Engbrecht in Winnipeg, Annie Calkins and Susan Stitham in Alaska, Mary Barr in San Diego, and Michael Hayhoe and Tony Adams in England. 


\section{References}

Frost, R. (1922). Stopping by woods on a snowy evening. 20 th century poetry \& poetics (Edited by Gary Geddes). Toronto: Oxford University Press, 1985.

Hardy, B. (1977).Towards a poetics of fiction: An approach through narrative. In M. Meek, A. Warlow \& G. Barton (Eds), The cool web: The pattern of children's reading. London: Bodley Head.

Hopkins, G.M. (1880). Spring and fall. Victorian poetry and poetics. Boston: Houghton Mifflin Company, 1968.
National Endowment for the Arts (2009). Reading on the rise: $A$ new chapter in American literacy. Washington, DC: Author.

Polanyi, M. (1966). The tacit dimension. Garden City, New York: Doubleday \& Co.

Rosenblatt, L. (1978). The reader, the text, the poem: The transactional theory of the literary work. Carbondale: Southern Illinois University Press.

Silverstein, S. (1974). Where the sidewalk ends. New York: Harper \& Row.

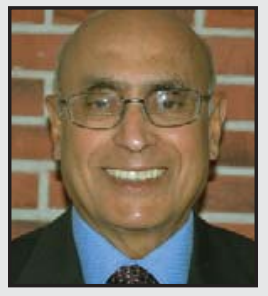

Patrick Dias is Emeritus Professor of Education at McGill University where he founded the Centre for the Study and Teaching of Writing and was its director for 12 years. He has researched response to literature among children, adolescents, and adults and the development of writing abilities in school and in workplace settings, publishing six books and several articles in these areas. In 1991 he was honoured by the Canadian Council of Teachers of English for distinguished contributions to the teaching of English in Canada. 